Images in...

\title{
Adrenocorticotropic hormone independent macronodular adrenal hyperplasia
}

Peter Mwamure, ${ }^{1}$ Kingsley Nirmalaraj, ${ }^{2}$ Louise Wolmarans ${ }^{3}$

${ }^{1}$ Middlemore Hospital, Auckland, New Zealand;

${ }^{2}$ Tauranga Hospital, Tauranga, New Zealand;

3Waikato Hospital, Hamilton, New Zealand

Correspondence to Dr Peter Mwamure, peter.mwamure@doctors.org.uk

\section{DESCRIPTION}

Figure 1 is of a CT scan showing bilateral macronodular adrenal glands in a patient with adrenocorticotropic hormone-independent macronodular adrenal hyperplasia (AIMAH).

AIMAH was first described in $1964^{1}$

AIMAH is often discovered as a fortuitous radiological finding, as in our patient, or during investigation for endogenous hypercortisolism. AIMAH represents less than 1\% of patients with endogenous Cushing's syndrome.

Most AIMAH patients are diagnosed in the fifth and sixth decades.

CT imaging normally shows bilateral adrenal nodules, which sometimes grow to as large as $5 \mathrm{~cm}$, often with a combined adrenal weight of more than $60 \mathrm{~g}^{2}$. Although recent AIMAH data suggest that larger adrenal nodules accumulate an increased number of genomic and transcript abnormalities, ${ }^{3}$ AIMAH is a benign process that has so far not been shown to become malignant.

The secretion of cortisol in most patients with AIMAH is under the influence of hormones other than adrenocorticotropic hormone, which stimulate aberrantly expressed receptors in the adrenal glands. ${ }^{2}$ Examples include G-protein coupled receptors for glucose-dependent insulinotropic peptide, $\beta$-adrenergic receptors, vasopressin (V2, V3) receptors, serotonin (5-hydroxytryptamine) receptors and leptin receptors.

La Croix has described useful protocols for identifying various aberrant receptors as well potential medical treatment options. ${ }^{2}$ Treatment for AIMAH includes specific blockade of aberrant receptors where applicable. When specific blockade of aberrant receptors is not possible, unilateral adrenalectomy is recommended in those patients with moderate steroid hormone excess. In patients with

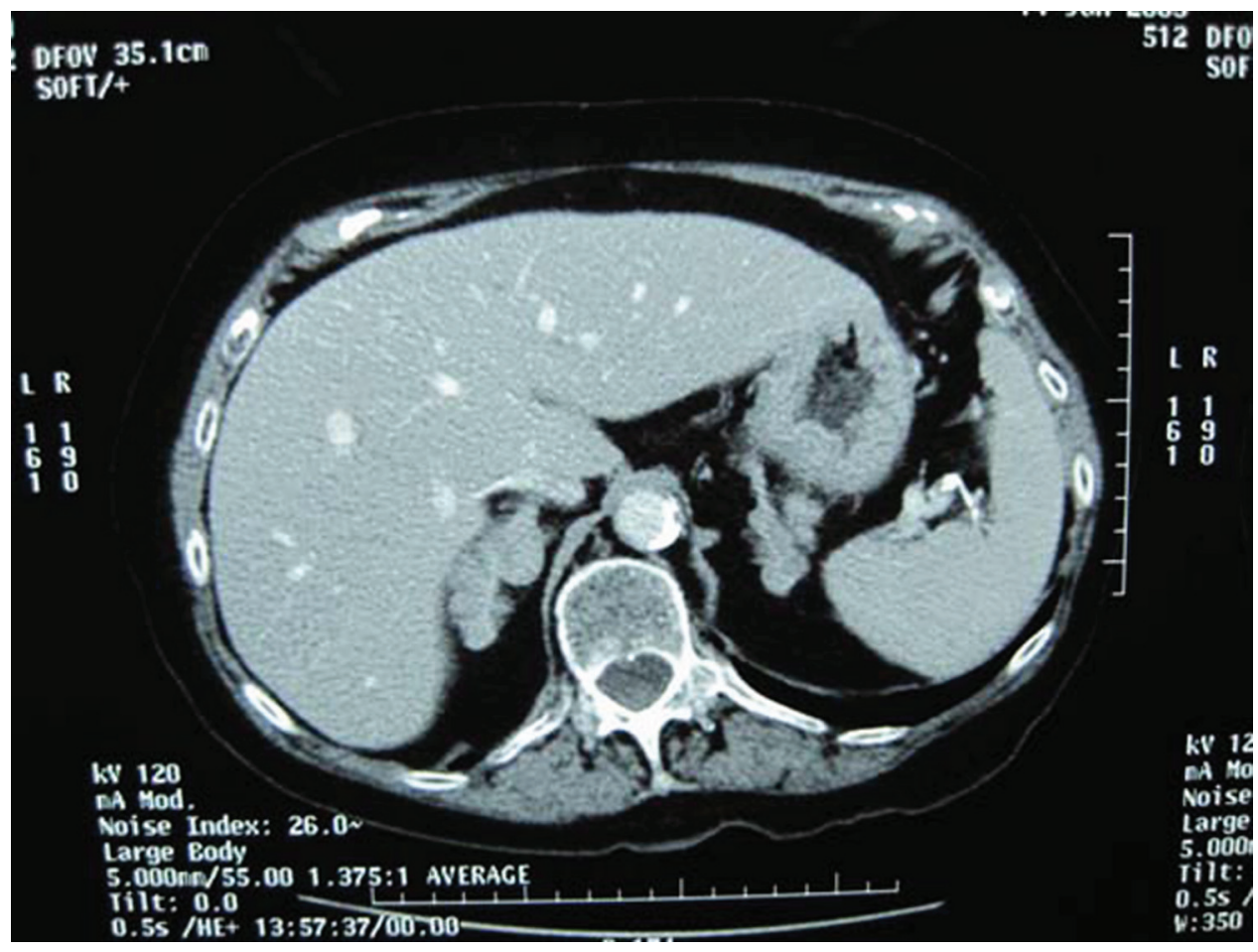

Figure 1 CT scan of the adrenal glands. 


\section{BMJ Case Reports}

very high levels of steroid hormone production, bilateral adrenalectomy is the treatment of choice.

Competing interests None.

Patient consent Not obtained.

\section{REFERENCES}

1. Kirshner MA, Powel RD Jr, Lipsett MB. Cushing's Syndrome: nodular cortical hyperplasia of adrenal glands with clinical and pathological features suggesting adrenocortical tumour. J Clin Endocrinol Metab 1964;24:947-55

2. Lacroix A. ACTH-independent macronodular adrenal hyperplasia. Best Pract Res Clin Endocrinol Metab 2009;23:245-59.

3. Almeida MQ, Harran M, Bimpaki El, et al. Integrated genomic analysis of nodular tissue in macronodular adrenocortical hyperplasia: progression of tumorigenesis in a disorder associated with multiple benign lesions. J Clin Endocrinol Metab 2011;96:E728-38.

This pdf has been created automatically from the final edited text and images.

Copyright 2011 BMJ Publishing Group. All rights reserved. For permission to reuse any of this content visit http://group.bmj.com/group/rights-licensing/permissions.

BMJ Case Report Fellows may re-use this article for personal use and teaching without any further permission.

Please cite this article as follows (you will need to access the article online to obtain the date of publication).

Mwamure P, Nirmalaraj K, Wolmarans L. Adrenocorticotropic hormone independent macronodular adrenal hyperplasia. BMJ Case Reports 2011; 10.1136/bcr.06.2011.4353, date of publication

Become a Fellow of BMJ Case Reports today and you can:

- Submit as many cases as you like

- Enjoy fast sympathetic peer review and rapid publication of accepted articles

- Access all the published articles

Re-use any of the published material for personal use and teaching without further permission

For information on Institutional Fellowships contact consortiasales@bmjgroup.com

Visit casereports.bmj.com for more articles like this and to become a Fellow 